\title{
Potentiality of Bamboos to Combat Climate Change Impacts and Biodiversity Conservation in the Annapurna Conservation Area, Nepal
}

\author{
Kabita Ghale ${ }^{1}$, Shailendra Kumar Yadav*, Neeru Thapa ${ }^{1}$, Jit Narayan Sah ${ }^{1}$ \\ ${ }^{1}$ Tribhuvan University, Institute of Forestry, Pokhara Campus, Pokhara, Nepal \\ ${ }^{2}$ Tribhuvan University, Institute of Forestry, Hetauda Campus, Hetauda 44107, Nepal \\ *corresponding author: shailendra.yadav@hc.tu.edu.np
}

\section{Abstract}

Diverse physiography and topography have made the landscape of Nepal fragile and highly vulnerable to climate change. Bamboo is likely to be highly able to stock carbon due to its rapid and easy growth. Here we explore the potentiality of bamboo to combat climate change impacts and biodiversity conservation through mitigation. The mitigation potentiality is studied through biomass and biomass carbon estimation along with soil carbon estimation. Data collected through participatory resource mapping, direct field observation and biophysical measurements were analyzed for biomass estimation and carbon stocking in the biomass and soil of bamboo stand, using Statistical analysis. The study revealed that Melocanna baccifera yielded the highest potential biomass carbon density of 109.41 tons C/plot, followed by Bambusa Nepalensis and Himalayacalamus Fimbriatus of 85.10 tonsC/plot and 64.58 tons C/plot, respectively. However, the soil under Himalayacalamus fimbriatus yielded the highest potential soil organic carbon of 49.24 tons C/plot, followed by the soil under Bambusa Nepalensis and Melocana Bacifera of 38.69 tons C/plot and 27.91 tons C/plot, respectively. Unsustainable extraction of bamboo was highly threatening, therefore, conservation education is recommended to aware local people of the importance of bamboo having the potential to fight against climate change and bringing harmony between biodiversity conservation and traditional culture is recommended.

Key words: Bamboo, Carbon sequestration, Climate Change, Biodiversity

\section{Introduction}

Climate Change has emerged as a worldwide issue with multiple causes and effects. People around the globe are suffering from scarcity of food, water and more frequent severe natural calamities, i.e. drought, flood, landslides, etc. due to climate change. Nepal, being a vulnerable Himalayan country, is not an exception. According to the UNFCCC (1992), climate change is "a change which is attributed directly or indirectly to human activity that alters the composition of the global atmosphere and which is in addition to natural climate variability observed over a comparable time period".

Professor John (Lou et al., 2010) as described the challenges brought by climate change as challenges requiring concurrent action on resilience, adaptation and mitigation (Lou et al., 2010). Climate change adaptation means preparing to acclimatize in changing context because of climate change. Mitigation is about reducing human impact on the climate system. 
Without mitigation, climate change would continue unchecked and eventually would outdo all our efforts to adapt (UNFCCC, 1992). Adaptation and mitigation should be followed by the sustainable and eco-friendly development. The forest ecosystem has been recognized to possess the ability to meet these challenges. As a unique part of the forest ecosystem, bamboo has gained continuous rising attention in recent decades due to its high ecological and socio-economic versatility and especially its great potential for carbon sequestration and its unique role in mitigating climate change (Li et al., 2003; Zhou et al., 2006; FAO, 2010).

Bamboos are pure grove or mixed with other species in the natural forest. They are also cultivated in gardens, farms and other agroforestry systems. They have significant advantages over other biomass resources due to their various properties like species diversity, vigorous growth, early establishment, potential to adapt to various soil and climatic conditions, short harvesting period, sustainable yield and diverse uses (Sudhakara and Jijeesh, 2015). Even after the harvest, the remaining underground biomass stores significant amount of carbon. Bamboos also provides a climate resilient form of income for millions of people of all backgrounds around the world throughout the year (INBAR, 2020).

Bamboo species found in Nepal are categorized mainly as large statured bamboo, i.e. "Bans" and small statured bamboo, i.e. Nigalo (Shrestha, 1989). Twenty three (23) genera and more than 81 species of bamboohavebeenidentified within wide range of climatic variation of Nepal (Poudyal, 2006). Experts say bamboos can store up to 1000 tons of carbon per hectare (INBAR, 2020). Community forests of Nepal sell carbon credits under the REDD+ mechanism which only includes the trees, but not bamboos which are technically grass species. Over the next few decades, climate change is very likely to affect the diversity of forestgenetic resources and this will eventually disturbthe distribution of forest tree species and the composition of forest. This is definitely the subject of concern when forests are considered as the best sink for carbon sequestration. So, to include the bamboos in potential carbon trade, it is very important to conduct studies for adequate data collection regarding carbon sequestration and carbon storage by bamboo stands and the soil under these stands, when most bamboo related studies are concentrated on its economic potential.

In case of Nepal, only a few studies are carried out for the biomass estimation of some species of bamboos (Oli and Kandel, 2005; Oli and Kandel, 2006). A research study by G.C. and Bhandari (2010) is the only study on carbon sequestration potential of bamboo (Dendrocalamus strictus) done in Nepal known to us. The implementation of effective management practices such as the selective culm cutting practiced in rural areas of Nepal in the 
home gardens, lead to both increase in above ground carbon sequestration and increase in soil organic carbon, and thus increased soil organic carbon can enhance the productivity of the land and enhance the quality and quantity of other environmental services (Nath and Das, 2012).
International Bamboo and Rattan Organization states sequestrating carbon, reducing carbon release, adaptation, restoration and livelihood enhancement as the five ways' bamboo can fight climate change. This research was carried out to study the mitigation potentiality of bamboo by estimating the net potential carbon

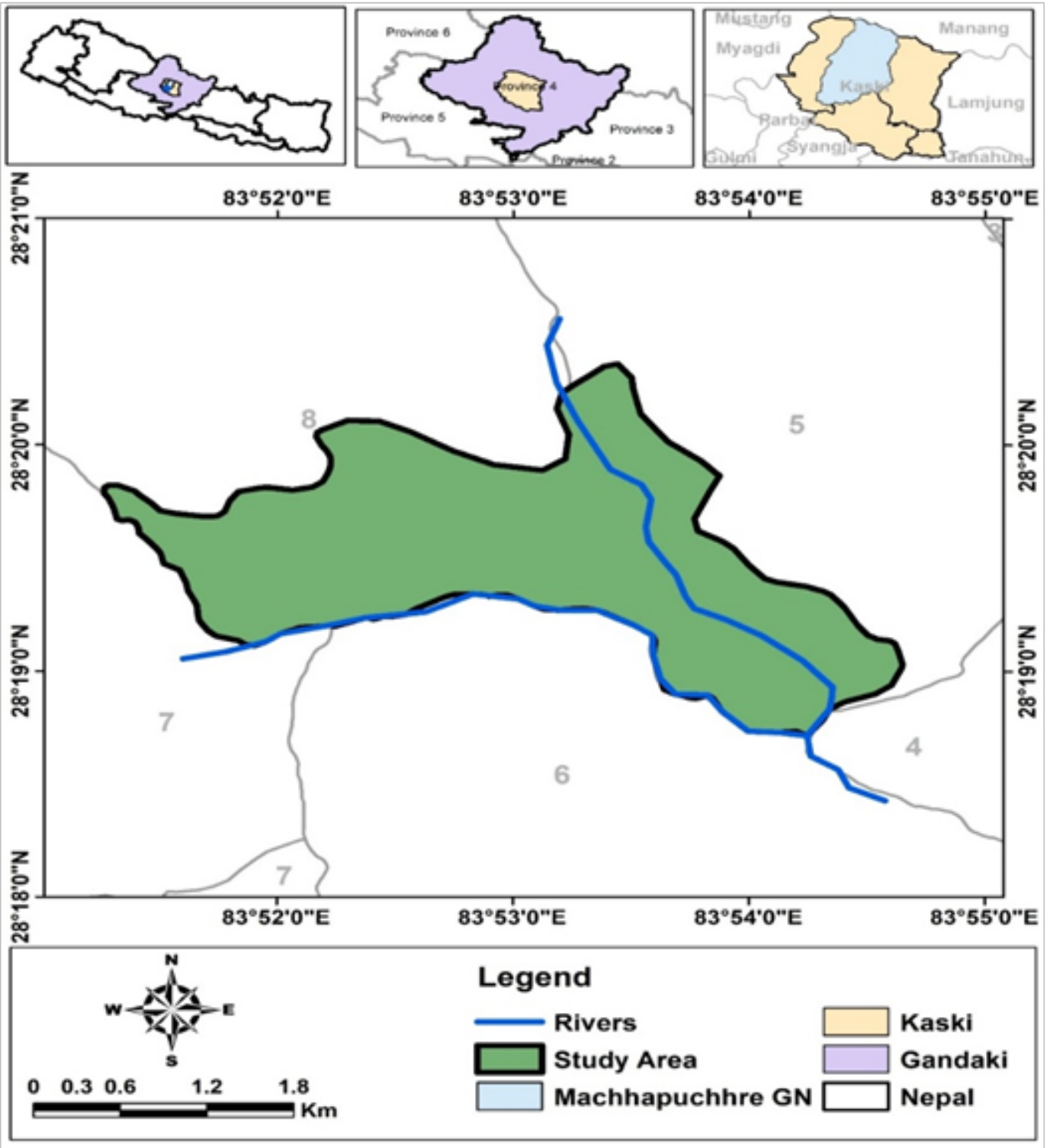

Figure 1: A map showing the study area 
density of the bamboo forest system \&soil under bamboo stands. It can be crucial to evaluate the role of bamboo in environmental conservation and economic sustainability. The collected data could serve as baseline information on carbon stock of the bamboo species for promotion of bamboo in climate change impact mitigation and adaptation.

\section{Materials and Methods}

\section{Study Area}

Covering an area of 7,629 sq. km., the Annapurna Conservation Area (ACA) is the first conservation area and the largest protected area of Nepal. Over 120,000 residents of different cultural and linguistic groups reside in this area. ACA has been divided into 7 Unit Conservation Offices-Jomsom, Lomanthang and Manang represent the Trans-Himalayan region while Bhujung, Sikles, Ghandrukand Lwang represent the Southern edge of the Annapurna region (NTNC, 2020).

Ward no. 8-Lwang of the Machhapuchre Rural Municiplaity of Kaski district, was chosen as the study area. It lies in the Lwang sector of the ACA. Altitude of Machhapuchre Rural Municipality varies from $1026 \mathrm{~m}$ at mean sea level to $6998 \mathrm{~m}$ of Mt. Machhapuchre. It covers an area of 544.58 sq.km. whereas ward no. 8 occupies an area of 20.23 sq. km. (www.machhapuchhremun.gov.np). The Lwang village is situated in front of the Machhapuchre Himal, at the top of the Mardi and Indhikhola at about 1300 meters from sea level.

\section{Methods}

\section{Primary data collection}

The data were collected based on reconnaissance survey and Participatory Resource Mapping was conducted to identify the potential areas where bamboo species are found. The key informant survey was done to know to get more information about bamboo. The key persons were residents and the members of the Conservation Area Management Committee (CAMC) from the study area and staffs of Unit Conservation Office (UCO) Lwang of the Annapurna Conservation Area Project (ACAP). Direct Field Observation was done to record the bamboo species in the study area and to record the total number of culms per clump.

\section{Sampling Procedures}

Purposive sampling was carried out due to the scarce distribution of bamboo species, since this type of sampling would allow us to choose the sample plot as per our convenience and avoid in accessible plots. Twelve (12) circular plots of radius $5.64 \mathrm{~m}$ and area $100 \mathrm{sq}$. $\mathrm{m}$. from 3 different elevation ranges were laid out using GPS, to estimate the bamboo biomass density and its biomass carbon density (Figure 2). One bamboo was felled from each plot for biophysical measurements to measure the length and diameter at breast height (dbh), and samples were taken for carbon analysis. 


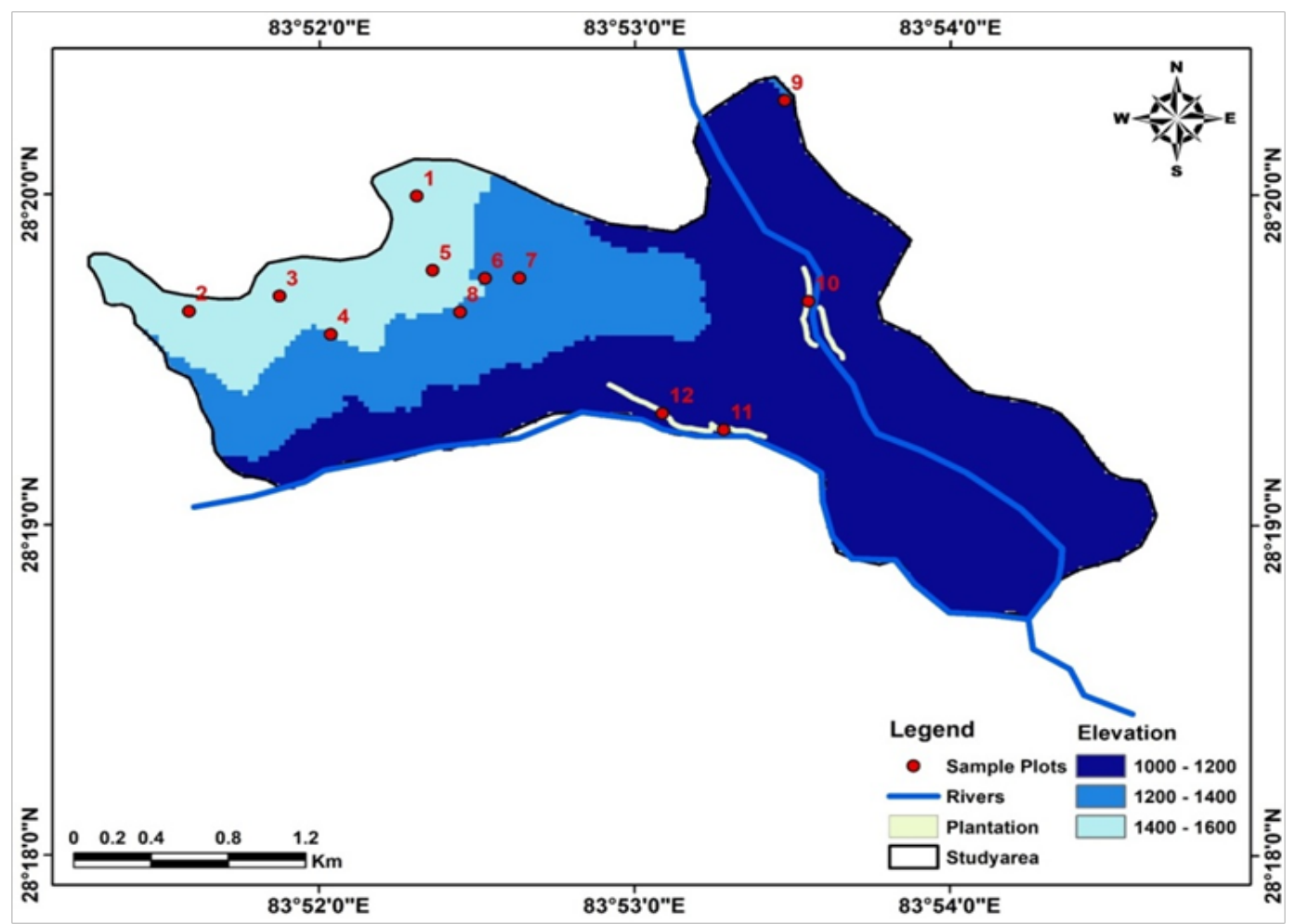

Figure 2: A map showing the distribution of sample plots according to the elevation

Soil samples were taken from soil density. The formula used was: CVF = profile depth at $(0-10) \mathrm{cm},(10-20) \mathrm{cm}$ and (20-30) $\mathrm{cm}$ at each plot (IPCC Guidelines) to study the carbon stored in the soil under the bamboo stands of 3 different species.

\section{Lab Analysis Procedures}

The samples of bamboo were dried in an oven at $80^{\circ} \mathrm{C}$ for 72 hours until the constant weight was attained for laboratory analysis.

\section{Biomass Estimation}

Above ground Biomass (AGB) Density Estimation: Conversion factor (CVF) was calculated to convert the fresh weight into oven dry weight for the estimation of above ground biomass (oven dry weight of sample/fresh weight of the sample)

Below ground Biomass (BGB) Density Estimation: Rhizome Biomass $=5 \%$ of culm biomass (Stokes et al., 2007).

\section{The carbon content estimation in culm and foliage of bamboo species}

Two (2) gram of each culm sample and 1 gm of each foliage sample were weighed and burnt at $550^{\circ} \mathrm{C}$. The following relation given by Allen et al. (1986) as cited in Sohel et al. (2015) was used to determine the carbon content: $\mathrm{C} \%=$ $(100-$ Ash \%) $\times 0.58$ (considering 0.58 $\%$ carbon in ash free materials) 


\section{Soil Carbon Estimation}

Organic Carbon Content (OCC) in the soil was estimated through Colorimetric method in Li-Bird Soil Lab. Bulk Density (BD) was calculated using Volume -Mass Replacement method as; $\mathrm{BD}=$ (weight of soil / volume of soil)

Total Soil Organic Carbon (SOC) was estimated using the formula by Chabbra et al., (2003) as; $\mathrm{SOC}=\mathrm{OCC}(\%) \times$ Soil Bulk Density $\left(\mathrm{kg} / \mathrm{m}^{3}\right) \times$ thickness of the horizon (m)

\section{Net Carbon Density Estimation}

Total AGB Carbon Density $=\{($ total culm biomass $\times \mathrm{C} \%)+$ (total leaf biomass $\times \mathrm{C} \%)\}$

Total BGB Carbon Density = total rhizome biomass of bamboo $\times \mathrm{C} \%$ and presented as required for the study.

\section{Results}

The four culms per bamboo species were sampled for biophysical measurements and laboratory analysis. The biophysical measurements showed that among the three bamboo species studied Tame bans (Bambusa Nepalensis) yielded the highest mean value of height and diameter as 12.68 $\mathrm{m}$ and $6.6 \mathrm{~cm}$, respectively. Fidim Bans (Melocana bacifera) showed the mean height and diameter of $9.86 \mathrm{~m}$ and 3.32 $\mathrm{cm}$ respectively, while Tite Nigalo (Himalayacalamus Fimbriatus) showed the mean height and diameter of $7.35 \mathrm{~m}$ and $1.67 \mathrm{~cm}$ respectively.

\section{Culm density measurement}

$H$. fimbriatus was found to have the

Table 1: Measurement data of the three bamboo species

\begin{tabular}{|c|l|c|c|c|c|}
\hline \multirow{2}{*}{$\begin{array}{c}\text { Elevation in } \\
\text { meter }\end{array}$} & \multirow{2}{*}{$\begin{array}{c}\text { Bamboo } \\
\text { species }\end{array}$} & \multicolumn{2}{|c|}{$\begin{array}{c}\text { Height of sample } \\
\text { culm in meter }\end{array}$} & \multicolumn{2}{c|}{$\begin{array}{c}\text { Diameter of sampled } \\
\text { culm in centimeter }\end{array}$} \\
\cline { 3 - 6 } & & Range & Mean & Range & Mean \\
\hline $1000-1200$ & M. bacifera & $8-12.6$ & 9.86 & $3.3-3.8$ & 3.32 \\
\hline $1200-1400$ & B. nepalensis & $11.22-16.57$ & 12.68 & $6.1-7.7$ & 6.6 \\
\hline $1400-1600$ & H. fimbriatus & $6.12-8.72$ & 7.35 & $1.3-2.1$ & 1.67 \\
\hline
\end{tabular}

\section{Statistical Analysis}

Descriptive statistics such as total, mean, percentage, etc. were used in comparing biomass, biomass carbon stored and soil organic carbon stored among the different bamboo species in the study area. Microsoft Excel and Statistical Package for Social Science (SPSS) were used for processing of data. The method and data analysis parts were re-checked highest mean culm density of 1275 culms per plot followed by $M$. bacifera with the mean culm density of 327.5 culms per plot and $B$. nepalensis with the mean culm density of 113.5 culms per plot. In the same order, $H$. fimbriatus showed the highest potential culm density of 127500 culms per ha followed by $M$. bacifera with the potential culm density of 32750 culms 
Table 2: The mean culm density of the three bamboo species

\begin{tabular}{|l|l|l|c|c|c|}
\hline Elevation in meter & \multicolumn{1}{|c|}{ Species } & Clumps & $\begin{array}{c}\text { Culm per } \\
\text { clump }\end{array}$ & Culm per plot & Culm per ha \\
\hline $1000-1200$ & M. bacifera & 4.25 & 72.5 & 327.5 & 32750 \\
\hline $1200-1400$ & B. nepalensis & 3.75 & 28.25 & 113.5 & 11350 \\
\hline $1400-1600$ & H. fimbriatus & 13 & 120 & 1275 & 127500 \\
\hline
\end{tabular}

per ha and $B$. nepalensis with the potential culm density of 11350 culms per ha.

\section{Above ground biomass density}

The above ground biomass density in the study area ranged from 1.06 tons per plot to 1.8 tons per plot. M.bacifera showed the highest mean above ground biomass density of 1.8 tons per plot followed by B. nepalensis of 1.4 tons per plot and H. fimbriatus of 1.06 tons per plot. The potential above ground biomass density of thin walled bamboo species like $M$. bacifera is 179.99 tons per ha, while the potential aboveground biomass density of thick-walled bamboos like $B$. nepalensisis 139.88 tons per plot.

Carbon stored in the aboveground biomass density

$M$. bacifera yielded the highest amount of aboveground carbon density of 1.04 tons per plot followed by $B$. nepalensis with the carbon density of 0.8 tons per plot and $H$. fimbriatus with the carbon density of 0.61 tons per plot. All the three bamboo species showed almost equivalent mean organic carbon content percentage in both the above ground biomass components, rounding to $57.9 \%$. The potential carbon stored in the aboveground biomass of these bamboo species are 104.2 tons per ha

Table 3: The aboveground biomass density of the three bamboo species

\begin{tabular}{|c|c|c|c|c|c|c|c|}
\hline $\begin{array}{l}\text { Elevation } \\
\text { (m) }\end{array}$ & $\begin{array}{l}\text { Bamboo } \\
\text { Species }\end{array}$ & $\begin{array}{c}\text { AGB } \\
\text { Component }\end{array}$ & $\begin{array}{c}\text { AGB } \\
\text { Density } \\
\text { (Tons/ } \\
\text { plot) }\end{array}$ & $\begin{array}{c}\text { AGB } \\
\text { Density } \\
\text { (Tons/ha) }\end{array}$ & $\begin{array}{l}\text { Mean } \\
\text { OCC, } \\
\% 78 m\end{array}$ & $\begin{array}{c}\text { Above } \\
\text { ground } \\
\text { Carbon } \\
\text { Density } \\
\text { (tons/plot) }\end{array}$ & $\begin{array}{l}\text { Above } \\
\text { ground } \\
\text { Carbon } \\
\text { Density } \\
\text { (tons/ha) }\end{array}$ \\
\hline \multirow{3}{*}{$1000-1200$} & \multirow{3}{*}{$\begin{array}{c}\text { A. } \\
\text { M.bacifera }\end{array}$} & Culm & 1.54 & 153.61 & 57.95 & 0.89 & 89.04 \\
\hline & & Foliage & 0.26 & 26.16 & 57.93 & 0.15 & 15.16 \\
\hline & & Total & 1.8 & 179.77 & & 1.04 & 104.2 \\
\hline \multirow{3}{*}{$1200-1400$} & \multirow{3}{*}{$\begin{array}{c}\text { B. } \\
\text { Nepalensis }\end{array}$} & Culm & 1.23 & 122.85 & 57.95 & 0.71 & 71.19 \\
\hline & & Foliage & 0.17 & 17.03 & 57.91 & 0.09 & 9.86 \\
\hline & & Total & 1.4 & 139.88 & & 0.8 & 81.05 \\
\hline \multirow{3}{*}{$1400-1600$} & \multirow{3}{*}{$\begin{array}{c}H . \\
\text { fimbriatus }\end{array}$} & Foliage & 0.82 & 81.92 & 57.95 & 0.47 & 47.47 \\
\hline & & Foliage & 0.24 & 24.23 & 57.93 & 0.14 & 14.04 \\
\hline & & Total & 1.06 & 106.15 & & 0.61 & 61.51 \\
\hline
\end{tabular}


Table 4: Carbon stored in the above ground biomass density of the three bamboo species

\begin{tabular}{|c|c|c|c|c|c|c|c|}
\hline $\begin{array}{l}\text { Elevation } \\
\text { in meter }\end{array}$ & $\begin{array}{l}\text { Bamboo } \\
\text { Species }\end{array}$ & $\begin{array}{c}\text { AGB } \\
\text { Component }\end{array}$ & $\begin{array}{c}\text { AGB } \\
\text { Density } \\
\text { (tons/ } \\
\text { plot) }\end{array}$ & $\begin{array}{c}\text { AGB } \\
\text { Density } \\
\text { (tons/ha) }\end{array}$ & $\begin{array}{c}\text { Mean } \\
\text { OCC, } \\
\%\end{array}$ & $\begin{array}{c}\text { Above } \\
\text { ground } \\
\text { Carbon } \\
\text { Density } \\
\text { (tons/plot) }\end{array}$ & $\begin{array}{c}\text { Above } \\
\text { ground } \\
\text { Carbon } \\
\text { Density } \\
\text { (tons/ha) }\end{array}$ \\
\hline \multirow{3}{*}{$1000-1200$} & \multirow{3}{*}{ M. bacifera } & Culm & 1.54 & 153.61 & 57.95 & 0.89 & 89.04 \\
\hline & & Foliage & 0.26 & 26.16 & 57.93 & 0.15 & 15.16 \\
\hline & & Total & 1.8 & 179.77 & & 1.04 & 104.2 \\
\hline \multirow{3}{*}{$1200-1400$} & \multirow{3}{*}{ B. Nepalensis } & Culm & 1.23 & 122.85 & 57.95 & 0.71 & 71.19 \\
\hline & & Foliage & 0.17 & 17.03 & 57.91 & 0.09 & 9.86 \\
\hline & & Total & 1.4 & 139.88 & & 0.8 & 81.05 \\
\hline \multirow{3}{*}{$1400-1600$} & \multirow{3}{*}{ H. fimbriatus } & Culm & 0.82 & 81.92 & 57.95 & 0.47 & 47.47 \\
\hline & & Foliage & 0.24 & 24.23 & 57.93 & 0.14 & 14.04 \\
\hline & & Total & 1.06 & 106.15 & & 0.61 & 61.51 \\
\hline
\end{tabular}

for $M$. bacifera, 81.05 tons per ha for $B$. nepalensis and 61.51 tons per ha for $H$. fimbriatus.

Carbon stored in the below ground biomass density

The below ground biomass of all three bamboo species was calculated as $5 \%$ of the aboveground biomass (Stokes et al., 2007). M. bacifera yielded the highest below ground carbon density of 0.05 tons/plot followed by B. nepalensis of 0.04 tons/plot and H. fimbriatus of 0.03 tons /plot.

\section{Carbon stored in the soil}

Bulk densities in the three different soil depths ranged from $0.72 \mathrm{gm} / \mathrm{cc}$ to 0.91 $\mathrm{gm} / \mathrm{cc}$ only for three different depths. The soil organic carbon and mean carbon content were highest in the 0-10 $\mathrm{cm}$ soil depth of the soils under all three bamboo species. Soil under M. bacifera was found to have the lowest soil organic carbon of 0.277 tons/plot while, in case of B. nepalensis, it increased by 0.108 tons/plot. The quantity further increased by 0.156 tons/plot for $H$. fimbriatus.

Table 5: Carbon stored in the below ground biomass density of the three bamboo species

\begin{tabular}{|c|l|l|l|l|l|l|l|}
\hline $\begin{array}{c}\text { Elevation } \\
\text { in meter }\end{array}$ & Species & $\begin{array}{c}\text { AGB } \\
\text { Density } \\
\text { (tons/ } \\
\text { plot) }\end{array}$ & $\begin{array}{c}\text { AGB } \\
\text { Density } \\
\text { (tons/ } \\
\text { ha) }\end{array}$ & $\begin{array}{c}\text { BGB } \\
\text { Density } \\
\text { (tons/ } \\
\text { plot) }\end{array}$ & $\begin{array}{c}\text { BGB } \\
\text { Density } \\
\text { (tons/ } \\
\text { ha) }\end{array}$ & $\begin{array}{c}\text { Below } \\
\text { ground } \\
\text { carbon } \\
\text { density } \\
\text { (tons/plot) }\end{array}$ & $\begin{array}{c}\text { Below } \\
\text { ground } \\
\text { carbon } \\
\text { density } \\
\text { (tons/ha) }\end{array}$ \\
\hline $1000-1200$ & M.bacifera & 1.8 & 179.77 & 0.09 & 8.98 & 0.05 & 5.21 \\
\hline $1200-1400$ & B. nepalensis & 1.4 & 139.88 & 0.07 & 6.99 & 0.04 & 4.05 \\
\hline $1400-1600$ & H. Fimbriatus & 1.06 & 106.15 & 0.05 & 5.3 & 0.03 & 3.07 \\
\hline
\end{tabular}


Total carbon stock

The total carbon density above ground, carbon density below ground, and spoil carbon of each bamboo species were

\section{Total potential carbon stock}

Total potential carbon stock varied from 113.82 tons $\mathrm{C} /$ plot to 137.32 tons $\mathrm{C} /$ plot. $M$. bacifera showed the highest potential

Table 6: Carbon stored in the soil of the three bamboo species

\begin{tabular}{|c|c|c|c|c|c|c|}
\hline $\begin{array}{l}\text { Elevation } \\
\text { in meter }\end{array}$ & $\begin{array}{c}\text { Bamboo } \\
\text { species }\end{array}$ & $\begin{array}{c}\text { Soil } \\
\text { Depth } \\
(\mathbf{c m})\end{array}$ & $\begin{array}{c}\text { Bulk } \\
\text { Density } \\
\text { (g/cc) }\end{array}$ & $\begin{array}{c}\text { Mean } \\
\text { Carbon } \\
\text { Content \% }\end{array}$ & $\begin{array}{c}\text { Soil Organic } \\
\text { Carbon } \\
\text { (tons/plot) }\end{array}$ & $\begin{array}{c}\text { Soil Organic } \\
\text { Carbon } \\
\text { (tons/ha) }\end{array}$ \\
\hline \multirow{4}{*}{$1000-1200$} & \multirow{4}{*}{ M. bacifera } & $0-10$ & 0.79 & 1.49 & 0.107 & 10.785 \\
\hline & & $10-20$ & 0.81 & 1.29 & 0.092 & 9.270 \\
\hline & & $20-30$ & 0.85 & 1.05 & 0.078 & 7.856 \\
\hline & & Total & & & 0.277 & 27.911 \\
\hline \multirow{4}{*}{$1200-1400$} & \multirow{4}{*}{ B. Nepalensis } & $0-10$ & 0.79 & 1.69 & 0.130 & 13.077 \\
\hline & & $10-20$ & 0.85 & 1.52 & 0.129 & 12.996 \\
\hline & & $20-30$ & 0.91 & 1.48 & 0.126 & 12.623 \\
\hline & & Total & & & 0.385 & 38.696 \\
\hline \multirow{4}{*}{$1400-1600$} & \multirow{4}{*}{ H. Fimbriatus } & $0-10$ & 0.72 & 2.33 & 0.168 & 16.863 \\
\hline & & $10-20$ & 0.80 & 2.01 & 0.162 & 16.203 \\
\hline & & $20-30$ & 0.83 & 1.95 & 0.161 & 16.178 \\
\hline & & Total & & & 0.491 & 49.244 \\
\hline
\end{tabular}

summed up to obtain the total carbon stock. Table 7 shows that $M$. bacifera obtained the highest total carbon stored of mean of 1.367 tons $\mathrm{C} /$ plot which is due to its highest above ground carbon density followed by $B$. nepalensis (1.225-tons $\mathrm{C} /$ plot) and $H$. fimbriatus (1.131-tons C/plot). carbon of 137.321 tons C/plot followed by $B$. nepalensis (123.796 tons C/plot) and $H$. fimbriatus (113.824 tons $\mathrm{C} / \mathrm{plot}$ ).

Here the potential carbon stock in three bamboo species is shown in percentage which follows the same pattern as the Figure 3.

Table 7: Total carbon stock in the three bamboo species

\begin{tabular}{|c|l|c|c|c|c|}
\hline $\begin{array}{c}\text { Elevation } \\
\text { in meter }\end{array}$ & Species & $\begin{array}{c}\text { Above ground } \\
\text { carbon density } \\
\text { (tons carbon/plot) }\end{array}$ & $\begin{array}{c}\text { Below ground } \\
\text { carbon density } \\
\text { (tons carbon/plot) }\end{array}$ & $\begin{array}{c}\text { SOC } \\
\text { (tons } \\
\text { carbon/ plot) }\end{array}$ & $\begin{array}{c}\text { Total carbon } \\
\text { stock (tons } \\
\text { carbon/plot) }\end{array}$ \\
\hline $1000-1200$ & M. bacifera & 1.04 & 0.05 & 0.277 & 1.367 \\
\hline $1200-1400$ & B. nepalensis & 0.8 & 0.04 & 0.385 & 1.225 \\
\hline $1400-1600$ & H. fimbriatus & 0.61 & 0.03 & 0.491 & 1.131 \\
\hline
\end{tabular}


Table 8: Total potential carbon stock in the three bamboo species

\begin{tabular}{|c|c|c|c|c|c|}
\hline $\begin{array}{c}\text { Elevation in } \\
\text { meter }\end{array}$ & Species & $\begin{array}{c}\text { Aboveground } \\
\text { carbon } \\
\text { density (tons } \\
\text { carbon/ha) }\end{array}$ & $\begin{array}{c}\text { Belowground } \\
\text { carbon } \\
\text { density (tons } \\
\text { carbon/ha) }\end{array}$ & $\begin{array}{c}\text { Soil organic } \\
\text { carbon } \\
\text { (tons } \\
\text { carbon /ha }\end{array}$ & $\begin{array}{c}\text { Total } \\
\text { carbon } \\
\text { stock (tons } \\
\text { carbon/ha) }\end{array}$ \\
\hline $1000-1200$ & M. bacifera & 104.2 & 5.21 & 27.911 & 137.321 \\
\hline $1200-1400$ & B. Nepalensis & 81.05 & 4.05 & 38.696 & 123.796 \\
\hline $1400-1600$ & H. Fimbriatus & 61.51 & 3.07 & 49.244 & 113.824 \\
\hline
\end{tabular}

\section{Discussion}

The height and diameter measurement in the study showed that Tame bans ( $B$. culm density of 1275 culms per plot due to its property of bearing many culms in clusters. The average culm per clump of 28.25 for B.nepalensis is comparable

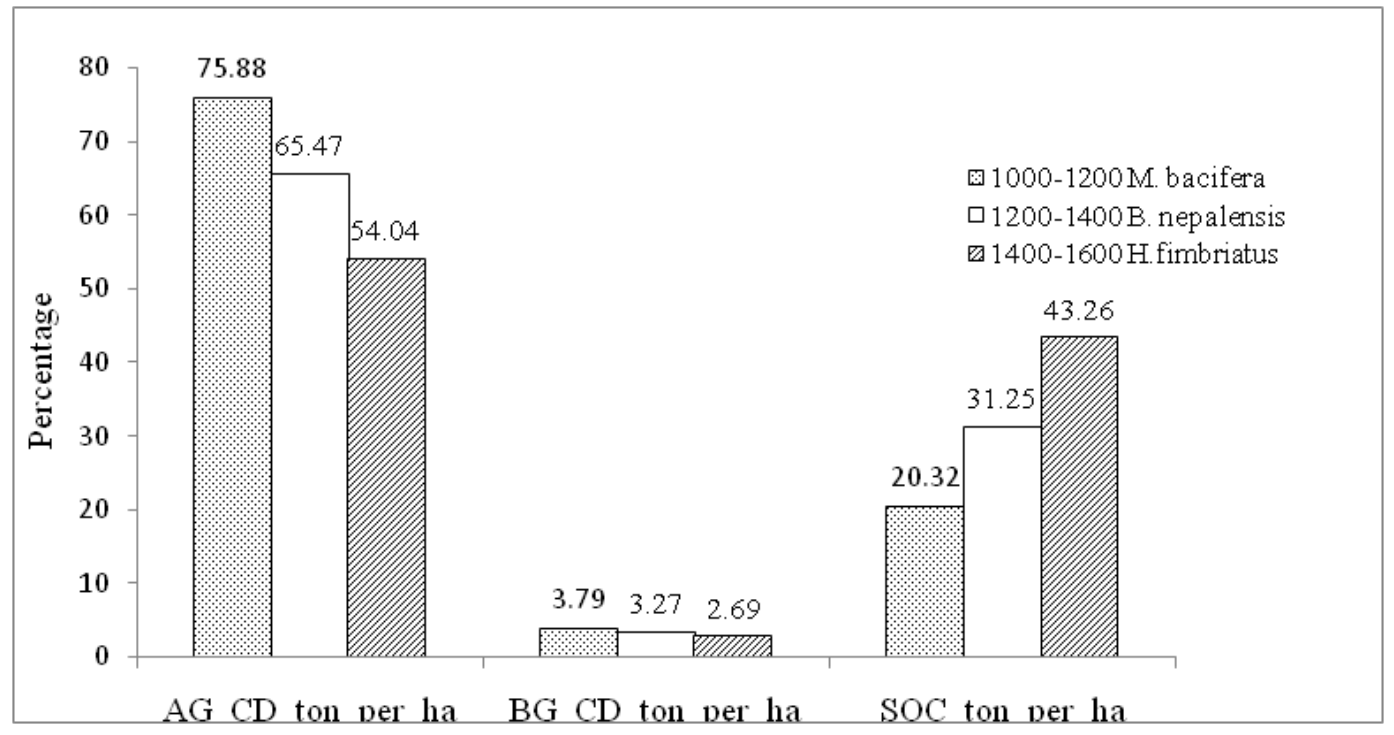

Figure 3: Potential carbon stock in three bamboo species

nepalensis) generated the highest mean value with height and diameter as 12.68 $\mathrm{m}$ and $6.6 \mathrm{~cm}$, respectively, which falls within 5-18 $\mathrm{m}$ height range and 4-9 $\mathrm{cm}$ diameter range for $B$. nutansas reported by Oli and Kandel (2005). The height range of M.bacifera of 8-12.6 m is comparable to that of $S$. lumampao which was 8.5-12.45 m (Pongon et al., 2016).

H. fimbriatus had the highest mean to the average of 32 culms per clump as reported by Tamang (2011) from the same area. As per the study by Singnar and Das (2017), the culm density of $M$. bacifera ranged from 34800 to 35600 culms per ha after the $4^{\text {th }}$ year of its flowering, which is comparable to the potential mean culm density of 32750 culms per ha.

Variation in species, soil fertility and stand age determines the biomass 
density of the bamboo species. $M$. bacifera showed the highest mean aboveground biomass density of 1.8 ton per plot which might be due to the management intervention as it was planted along the bank of a riverside with the embankment especially for the protection of the paddy field. The potential aboveground biomass density of thin-walled bamboo species like $M$. bacifera is 179.99 ton per ha which is almost equivalent to that of thick-walled bamboos. The potential aboveground biomass density of $B$. nepalensis falls within the range of $B$. bambos in India which was 122-287 tons/ha conducted by Shanmughavel \& Franchis (1996).

The average carbon content of the diverse culm components of 3 bamboo species didn't vary significantly as it ranged from $57.91 \%$ to $57.95 \%$ only. So, the highest above ground biomass of $M$. bacifera resulted in its highest carbon content stored. Since, the below ground biomass of all three bamboo species was calculated as $5 \%$ of the above ground biomass (Stokes et al., 2007), the below ground biomass was achieved in the same order of the above ground biomass. Christanty and Kimmins et al. (1996) stated that after culm harvest, large parts of the below ground biomass survive, preserving much of the sequestrated carbon.

The highest mean value of the carbon content of $2.33 \%$ and the highest mean value of potential SOC of 49.24 ton per ha of $H$. fimbriatus could be due to the moist soil condition in the south facing slope throughout where this species distribution occurs. This will further result in high carbon content potential. The mean carbon content percent and soil organic carbon decreased with the increase in depth of soils under all three bamboo species.

The total carbon stock was found to be high in the above ground biomass carbon density of $M$. bacifera which was distributed along the elevation range of 1000-1200 $\mathrm{m}$ in the study area along the river banks, and contributed $76.07 \%$ of the total carbon stock of this species. Below ground biomass carbon density contributed $3.65 \%$, and soil organic carbon contributed $20.26 \%$ of its total carbon stock. But in the case of $H$. fimbriatus, SOC was found to be the highest, contributing $43.41 \%$ of the total carbon stock of this species. Above ground biomass carbon density contributed $53.93 \%$ and below ground biomass carbon density contributed $2.65 \%$ of its total carbon stock.

M. bacifera showed the highest potential carbon of 137.321 tons C/plot followed by $B$. nepalensis (123.796 tons C/plot) and $H$. fimbriatus (113.824 tons $\mathrm{C} /$ plot). These all are higher compared to the total carbon sequestration by B. vulgaris in the degraded tropical forest of Lawacharra forest reserve of Bangladesh which is 77.67 tons $\mathrm{C} / \mathrm{ha}$ (Sohelet et al., 2015). All the bamboo species selected for research showed higher carbon sequestration potential ranging from 61.51 tons/ha to 104.2 tons/ha for above ground biomass and 
from 3.07 tons/ha to 5.21 tons/ha for below ground biomass in comparison to carbon sequestration of 1.66 ton/ha for above ground biomass and 0.08 ton/ha for below ground biomass by Dendrocalamus strictus, but lower in case of soil carbon (G.C. and Bhandari, 2010).

The findings from the research in village bamboos in the Barak Valley of North East India reveal management of village bamboo grooves by smallholder farmers as an important source of the carbon dioxide sink, making this an appropriate choice for such purposes (Nath and Das, 2012). The carbon stock of bamboo in Fujian Province China where the climate is more suitable for bamboo growth than in Zhejiang Province China, exceeded Pinuselliotti in its 19th year, Chinese Fir in its 15th year, and thus stored carbon stock was comparable to the broad-leaved forest of 262.5 tons' carbon per hectare and tropical forest of 230.4 tons' carbon per hectare (Lou et al., 2010). The bamboo related studies done in Nepal are focused mainly on economic aspects. Few studies related to bamboo biomass are limited to the biomass table (G.C and Bhandari, 2010).

\section{Conclusion}

M.baccifera yielded the highest above ground carbon density of 1.04-ton-C/plot, whereas soils under the $\mathrm{H}$. fimbriatus stand yielded the highest SOC of 0.5 -ton-C/plot. The culm part or above ground biomass contributed more tothe total biomass of the clump than the rhizome portion. Dry culms of B. nepalensis were found indicating poor management and harvesting practices of this thick-walled bamboo. There is need of scientific knowledge and advanced technology for the proper and urgent management intervention regarding bamboo plantation and harvesting, which is crucial for the sustainable yield of bamboo. The cottage industries promoting bamboo handicrafts like doko, daalo, nanglo should be encouraged as people still use those bamboo products in their day to day life. Conservation education should be given to aware people regarding the importance of large and small statured bamboos in the balance of biodiversity and the traditional culture. The plantation of $M$. bacifera should be extended along the overall length of the river bank rather than only in some portions. People should be made aware for the proper utilization of bamboo in bioengineering for soil and watershed conservation as direct impact of climate change is first seen in land and water resources. Hence, this type of research should be encouraged in different parts of Nepal for various other bamboo species.

\section{Conflict of Interest}

The authors declare no conflict of interest.

\section{References}

Chabbra, A., Palria, S. and Dadhwal, V.K. 2003. Soil Organic Carbon Pool in Indian Forests. 
Forest Ecology and Management 1739(1): 187-199. doi: 10.1016/S03781127(02)00016-6.

Christainty, L. and Kimmins, J.P. 1996. "Without bamboo, the land dies": Biomass, litterfall, and soil organic matter dynamics of a Javanese bamboo talun-kebun system. Forest Ecology and Management, Volume 87, Issues 1-3, Pages 75-88. https://doi. org/10.1016/S0378-1127(96)03834-0.

FAO. 2010. Global Forest Resource Assessment 2010: Main report. Food and Agriculture Organization of the United Nations, Rome.

G.C., D.B. and Bhandari, J. 2010. Carbon sequestration potential and uses of Dendrocalamusstrictus.A case study from Baglung District, Sigana VDC, Nepal. In SimHeok-Choh (Eds.), Proceeding of Asia and the Pacific Forest Products Workshop, IUFRO World Series, Vol. 27 pp 62-66. Colombo, Srilanka.

INBAR. 2020. Five ways bamboo can fight climate change. Available online at www.inbar. int/five-ways-bamboo-can-fight-climatechange/; last accessed Nov. 14, 2020.

Karki, M.B., Sherchan, G.R. and Karki, J.B.S. 1998. Extensive Bamboo Production-toConsumption Systems in Eastern Nepal: A Case Study. INBAR, Working Paper No. 17 .

Lou, Y., Li, Y., Buckingham, K., Henley, G. and Zhou, G. 2010. Bamboo and Climate Change Mitigation. International Network for Bamboo and Rattan(INBAR), Beijing. Technical Report No. 32.

Machhapuchhre Rural Municipality. 2020. Brief Introduction of Machhapuchre Rural Municipality. Available online at www.machhapuchhremun.gov. np/content/introduction; last accessed Nov. 15, 2020.

Nath, A.J. and Das, A.K. 2012. Ecological implications of village bamboo as global climate change mitigation strategy: A case study in Barak Valley, Assam,
North East India. International Journal of Climate Change Strategies and Management, Vol.4 Iss: 2 pp. 201-215.

NTNC. 2020. Annapurna Conservation Area Project (ACAP). Available online at www.ntnc.org.np/project/annapurnaconservation-area-project-acap; last accessed Nov. 15, 2020.

Oli, B.N. and Kandel, C.M. 2005. Biomass estimation of Bambusanutanssubspeciescupulata grown at Eastern Terai, Nepal. BankoJankari, Vol. 15, No. 2.

Pongon, R.S., Aranico, E.C., Dagoc, F.L.S. and Amparado, R.F. 2016. Carbon stock assessment of bamboo plantations in Northern Mindanao, Philippines. Journal of Biodiversity and Enviromental Sciences 9(6):97-112.

Poudyal, P. 2006. Bans kosikchha (Education on Bamboo). Swayambhu Environmental Education 171-202. Swyambhu Printing Press, Swyambhu, Kathmandu, Nepal.

Shanmughavel, P. and Franchis, K. 1996. Above ground biomass production and nutrient distribution in growing bamboo (Bambusabambos (L) Voss). Biomass and Bioenergy, Volume 10, Issue 5-6, Pages 383-391.

Shrestha, K. Distribution and status of bamboos in Nepal. Available online at www. biodiversityinternational.org; last accessed Sep. 9, 2018.

Singnar, P. and Das, A.K. 2017. Allometric scaling, biomass accumulation and carbon stocks in different aged stands of thin walled bamboos Schizostachyumdullooa, Pseudostachyumpolymorphumand Melocanabacifera. Forest Ecology and Management, Volume 395, Pages 81-91.

Sohel, M.S.I., Alamgir, M., Akhter, S. and Rahman, M. 2015. Carbon storage in a bamboo (Bambusa vulgaris) plantation in the degraded tropical forests: Implications for policy development. Land Use Policy 49(2015) 142-151. http://dx.doi.org.10. 1016/j.landusepol.2015.07.011

Stokes, A., Lucas, A. and Jouneau, L. 2007. Plant 
biochemical strategies in response to frequent disturbance: uprooting of Phyllostachysnidularia growing on landslide-prone slopes in Sichuan, China. Am.J. Bot. 94, 1129-1136.

Sudhakara, K. and Jijeesh, C.M. 2015. Bamboos: Emerging carbon sink for global climate change mitigation. National Workshop on Carbon Sequestration in Forest and Non- Forest Ecosystem.

Tamang, K. 2011. Assessing People's Interest and Cultivation Practice of Bamboo on Private Land: A Case Study from Lwangghalel VDC, Kaski, Nepal. B.Sc. Thesis. Tribhuvan University/ Institute of Forestry, Pokhara, Nepal.

UNFCCC. 1992. United Nations Framework Convention on Climate Change. New York, United Nations, General Assembly. 